\title{
DESIGN OF AN AUTOMOTIVE DIFFERENTIAL WITH REDUCTION RATIO GREATER THAN 6
}

\author{
Sumair Sunny ${ }^{1}$, Siddhesh Ozarkar², Sunny Pawar \\ ${ }^{1}$ Maharashtra Institute of Technology, Maharashtra, India \\ ${ }^{2}$ Maharashtra Institute of Technology, Maharashtra, India \\ ${ }^{3}$ Maharashtra Institute of Technology, Maharashtra, India
}

\begin{abstract}
Commonly found automobile differentials have a reduction ratio of 6 at max. This is because designing an automotive differential with a reduction ratio greater than 6 may lead to a bulky design which isn't feasible to position with the limited space available. Furthermore, increasing the size of the differential may lead to excessive undesired weight. Most on-road vehicles have differentials with reductions of 3 or 4. Commercially speaking, finding a differential with a reduction greater than 6 is close to impossible. Most manufacturers would introduce an additional single speed gearbox however this would over complicate the design and increase servicing costs. The aim of this paper is to design a differential with a reduction ratio greater than 6. The paper includes all the calculations as well as a strength based analysis performed on Altair-Hypermesh, to prove the success of the design.
\end{abstract}

Keywords: Worm, differential, over-running, self-locking, bevel, gear, bearing, reduction ratio

\section{INTRODUCTION}

We shall now design a differential using a worm gear reduction around the miter gear set. This is inspired from the "Napier Worm Gear Drive" invented by the British "Napier \& Sons" before the First World War. The company was later consumed by "English Electric" however their concept of a worm drive seems very promising.

\subsection{Input Parameters}

$\begin{array}{ll}\text { Input power: } & 5.8913 \mathrm{~kW} \\ \text { Input Speed: } & 4100 \mathrm{rpm} \\ \text { Input Torque: } & 13.7231 \mathrm{Nm} \\ \text { Reduction Ratio Reqd.: } & 7: 1\end{array}$

\subsection{Design Objective}

To design a differential offering a reduction ratio of 7 (7:1). It reduces output speed 7 times and multiplies output torque 7 times.

\section{DESIGN OF INNER BEVEL SET [2]}

\subsection{Constraints for Inner Bevel Set}

\section{Miter Gears:}

Pitch geometry (D)

Pitch cone Angle $(\varphi)$

Back cone Angle ( $\beta$ )

Pressure Angle ( $\psi)$

Module (m)

Velocity Ratio $(\mathrm{G})$

$$
\begin{aligned}
& =80 \mathrm{~mm} \\
& =45^{\circ} \\
& =45^{\circ} \\
& =20^{\circ} \\
& =4 \mathrm{~mm} \\
& =1(1: 1)
\end{aligned}
$$

\subsection{Sizing of Inner Bevel Set}

Pitch Cone Distance (AO):

$$
\mathrm{AO}=\sqrt{\left(\frac{D 1}{2}\right)^{2}+\left(\frac{D 2}{2}\right)^{2}}
$$

But $\mathrm{D}_{1}=\mathrm{D}_{2}$

$$
\begin{aligned}
& \mathrm{AO}=\sqrt{2 *\left(\frac{D 1}{2}\right)^{2}} \\
& \mathrm{AO}=\sqrt{2 *\left(\frac{80}{2}\right)^{2}}
\end{aligned}
$$

$\mathrm{AO}=56.67 \mathrm{~mm}$

Face Width (b):

$\left.\begin{array}{l}\mathrm{b}=\frac{A O}{3} \\ \text { or } \\ \mathrm{b}=10 \mathrm{~m}\end{array}\right\}$ whichever is lesser

$\mathrm{b}=\frac{56.67}{3}=19 \mathrm{~mm}$

$\mathrm{b}=10 * 4=40 \mathrm{~mm}$

$\therefore \mathrm{b}=19 \mathrm{~mm}$

Height of Addendum $\left(h_{a}\right)$ :

$$
\begin{aligned}
& \mathrm{h}_{\mathrm{a}}=1 * \mathrm{~m} \\
& =1 * 4 \\
& =4 \mathrm{~mm}
\end{aligned}
$$




\section{Height of Dedendum $\left(h_{f}\right)$ :}

$\mathrm{h}_{\mathrm{f}}=1.25 * \mathrm{~m}$

$=1.25 * 4$

$=5 \mathrm{~mm}$

Mean Radius $\left(\mathbf{R}_{\text {mean }}\right)$ :

$\mathrm{R}_{\text {mean }}=\frac{D}{2}-\frac{b}{2} \sin (\varphi)$ $=\frac{80}{2}-\frac{19}{2} \sin (45)$
$=33.28 \mathrm{~mm}$

Minimum Number of Teeth on Pinion $\left(Z_{\min }\right)$ :

$$
\begin{gathered}
\mathrm{Zmin}=\frac{2 \mathrm{hacos}(\varphi)}{m(\sin (\emptyset))^{2}} \\
\mathrm{Zmin}=\frac{2 * 4 \cos (45)}{4(\sin (20))^{2}} \\
\mathrm{Zmin}=12.08 \text { teeth } \approx 13 \text { teeth }
\end{gathered}
$$

Actual Number of Teeth $\left(Z_{\text {act }}\right)$ :

$$
\begin{gathered}
D=m * Z \\
80=4 * Z \\
Z=20 \text { teeth }
\end{gathered}
$$

Since $Z_{\text {act }}>Z_{\min } \quad$ PERMISSIBLE

\subsection{Force Analysis of Inner Bevel Set}

Torque acting on Bevel Set $(\mathrm{T})=96.0617 \mathrm{Nm}$ $=96061.7 \mathrm{Nmm}$

Speed of rotation of Bevel Set $=585.7143 \mathrm{rpm}$

Tangential Force $\left(\mathrm{F}_{\mathrm{T}}\right)=\frac{T}{\text { Rmean }}$

$\mathrm{F}_{\mathrm{T}}=\frac{96061.7}{585.7143}$

$\left(\mathrm{F}_{\mathrm{T}}\right)=2886.021811 \mathrm{~N}$

\section{Radial Force on Pinion $\left(\mathbf{F}_{\mathbf{R}}\right)$ :}

$\mathrm{F}_{\mathrm{R}}=\mathrm{F}_{\mathrm{T}} \tan (\psi) \cos (\varphi)$

$\mathrm{F}_{\mathrm{R}}=\mathrm{F}_{\mathrm{T}} \tan (20) \cos (45)$

$\mathrm{F}_{\mathrm{R}}=742.649 \mathrm{~N}$

$\therefore \mathrm{F}_{\mathrm{R}}=\mathrm{F}_{\mathrm{A}}=742.649 \mathrm{~N}($ MITER GEAR)

Pitch Line Velocity $\left(V_{m}\right)$ :

$\mathrm{V}_{\mathrm{m}}=\frac{\pi \mathrm{DN}}{60000}$

(Where, $\mathrm{D}_{\mathrm{m}=}$ mean diameter $\left.=2 * \mathrm{R}_{\text {mean }}\right)$

$\mathrm{V}_{\mathrm{m}}=\frac{\pi *(2 * 33.28) * 585.7143}{60000}$
$\mathrm{V}_{\mathrm{m}}=2.04 \mathrm{~m} / \mathrm{s}$

Velocity Factor $\left(\mathrm{C}_{\mathrm{v}}\right)=\frac{6}{6+V}$

$\left(C_{v}\right)=\frac{6}{6+2.04}=0.74621$

Equivalent Teeth on Pinion $\left(Z_{\mathrm{ep}}\right)$ :

$Z_{\text {ep }}=\frac{Z p}{\cos (\varphi) \cos ^{3}(\beta)}$

$\mathrm{Z}_{\mathrm{ep}}=\frac{20}{\cos (45) \cos ^{3}(45)}$

$\mathrm{Z}_{\mathrm{ep}}=80$ teeth

Lewis factor $\left(\mathrm{y}^{\prime}\right)=0.154-\frac{0.912}{\text { Zep }}$

$\mathrm{y}^{\prime}=0.154-\frac{0.912}{80}=0.1426$

\subsection{Material Selection}

Alloy Steel - $15 \mathrm{Ni} 4 \mathrm{Cr} 1$

$\mathrm{S}_{\mathrm{ut}}=1500 \mathrm{~N} / \mathrm{mm}^{2}$

$\mathrm{BHN}=650$

This selection is based on the design of worm gears as well. The aim is to use as few different materials so as to be able to make maximum use of recyclable metal scrap. The worm is case hardened alloy steel $(15 \mathrm{Ni} 4 \mathrm{Cr} 1)$ and worm wheel (which should be always be made of a more ductile material than worm) is made of Phosphor Bronze.[1]

The scrap material can be collected, melted and recast into machinable billets. This reduces cost of waste.

We shall consider a factor of safety of 1.5

$\sigma_{\mathrm{b}}=$ Allowable Bending Stress

$\sigma_{\mathrm{b}}=\frac{S u t}{3}=\frac{1500}{3}=500 \mathrm{~N} / \mathrm{mm}^{2}$

\subsection{Stress Based Analysis of Inner Bevel Set}

Beam Strength $\left(\mathbf{S}_{\mathrm{b}}\right)$ :

$\mathrm{S}_{\mathrm{b}}=\sigma_{\mathrm{b}} * \mathrm{C}_{\mathrm{v}} * \mathrm{~b} * \pi * \mathrm{~m} * \mathrm{y}^{\prime} * \frac{A o-b}{A o}$

$\mathrm{S}_{\mathrm{b}}=500 * 0.7462 * 19 * \pi * 4 * 0.1426\left(\frac{56.57-19}{56.57}\right)$

$\mathrm{S}_{\mathrm{b}}=8432.34 \mathrm{~N}$

\section{Ratio Factor (Q):}

$\mathrm{Q}=\frac{2 Z g}{Z g+Z g \tan (\varphi)}$

$\mathrm{Q}=1$ (MITER GEARS) 


\section{Load Stress Factor (K):}

$\mathrm{K}=0.16\left(\frac{B H N}{100}\right)^{2} \quad$ (Steel Gears $)$

$\mathrm{K}=0.16\left(\frac{650}{100}\right)^{2}$

$\mathrm{K}=6.76$

Wear Strength $\left(\mathbf{S}_{\mathrm{w}}\right)$ :

$\mathrm{S}_{\mathrm{w}}=\frac{0.75 * D * b * Q * K}{\cos (\varphi)}$

$\mathrm{S}_{\mathrm{w}}=\frac{0.75 * 80 * 19 * 1 * 6.76}{\cos (45)}$

$\mathrm{S}_{\mathrm{w}}=10894.15 \mathrm{~N}$

Service factor $\left(\mathrm{K}_{\mathrm{a}}\right)=1$

Load concentration factor $\left(\mathrm{K}_{\mathrm{m}}\right)=1.2$

Max Tangential Force $\left(\mathrm{F}_{\mathrm{T} \max }\right)$

$\mathrm{F}_{\mathrm{Tmax}}=\mathrm{K}_{\mathrm{a}} * \mathrm{~K}_{\mathrm{m}} * \mathrm{~F}_{\mathrm{T}}=1 * 1.2 * 2886.020=3463.22 \mathrm{~N}$

Tolerance Factor $\left(\emptyset_{\mathrm{p}}\right)$ :

$\emptyset_{\mathrm{p}}=\mathrm{m}+0.25 \sqrt{2 \text { Rmean }}$

$\emptyset_{\mathrm{p}}=4+0.25 \sqrt{2 * 33.28}$

$\emptyset_{\mathrm{p}}=6.039$

\section{Error (ep) considering IS Grade 5:}

$\mathrm{e}=5+0.4\left(\emptyset_{\mathrm{p}}\right)$

$\mathrm{e}=5+0.4(6.039)$

$\mathrm{e}=7.416 \mu \mathrm{m}$

\section{Total Error (e):}

$\mathrm{e}=\left(\mathrm{e}_{\mathrm{p}}+\mathrm{e}_{\mathrm{g}}\right) * 1000$

$\mathrm{e}=0.01483 \mathrm{~mm}$

\section{Deformation Factor (C):}

$\mathrm{C}=11500 * \mathrm{e}$

$\mathrm{C}=11500 *(0.0148)$

$\mathrm{C}=169.08 \mathrm{~N} / \mathrm{mm}$

\section{Incremental Dynamic Load $\left(\mathbf{F}_{\mathbf{d}}\right)$ :}

$\mathrm{F}_{\mathrm{d}}=\frac{21 V(C e b+F t)}{21 V+\sqrt{C e b+F t}}$

$\mathrm{F}_{\mathrm{d}}=\frac{21 * 2.04(169.08 * 0.01483 * 19)+2886.02)}{(21 * 2.04)+\sqrt{(169.08 * 0.01483 * 19)+2886.02}}$
$\mathrm{F}_{\mathrm{d}}=1295.79 \mathrm{~N}$

Effective Load $\left(\mathbf{F}_{\text {eff }}\right)$ :

$\mathrm{F}_{\text {eff }}=\mathrm{F}_{\mathrm{Tmax}}+\mathrm{F}_{\mathrm{d}}$

$\mathrm{F}_{\text {eff }}=3463.22+1295.79=4759.026 \mathrm{~N}$

Factor of Safety in Bending:

$(\mathrm{FOS})_{\mathrm{b}}=\frac{S b}{\text { Feff }}=\frac{8432.34}{4759.026}=1.77$

$(\mathrm{FOS})_{\mathrm{b}}>(\mathrm{FOS})_{\mathrm{reqd}}:$ DESIGN IS SAFE

Factor of Safety in Wear:

$(\mathrm{FOS})_{\mathrm{w}}=\frac{S w}{\text { Feff }}=\frac{10894.15}{4759.026}=2.28$

$(\mathrm{FOS})_{\mathrm{w}}>(\mathrm{FOS})_{\mathrm{reqd}}:$ DESIGN IS SAFE

\section{Shear Stress on Hollow Bevel Drive Shaft:}

Inner Diameter $\left(\mathrm{d}_{\mathrm{i}}\right)=27 \mathrm{~mm}$

Outer Diameter $\left(\mathrm{d}_{\mathrm{o}}\right)=35 \mathrm{~mm}$

Permissible Shear stress $\left(\tau_{\text {per }}\right)$

$\tau_{\text {per }}=\frac{0.5 \mathrm{Sut}}{\text { FOS }}=\frac{0.5 * 1500}{1.5}=500 \mathrm{~N} / \mathrm{mm}$

$\tau_{\text {actual }}=\frac{16 T}{\pi D o^{3} *\left(1-C^{4}\right)}$

Where, $\mathrm{C}=\frac{\mathrm{di}}{\mathrm{do}}$

$\tau_{\text {actual }}=\frac{16 * 96061.7}{\pi(35)^{3} *\left(1-\left(\left(\frac{27}{35}\right)^{4}\right)\right)}$

$\tau_{\text {actual }}=17.67 \mathrm{~N} / \mathrm{mm}^{2}$

Since $\tau_{\text {actual }}>\tau_{\text {per }}$ DESIGN IS PERMISSIBLE

\subsection{Bevel Shaft Spline Calculation}

Permissible pressure on splines $=6.5 \mathrm{~N} / \mathrm{mm}^{2}$ (Internal splines)

Major Diameter of Splines $\left(D_{\mathrm{s}}\right)=27 \mathrm{~mm}$

Minor Diameter of Splines $\left(\mathrm{d}_{\mathrm{s}}\right)=23 \mathrm{~mm}$

Number of Splines $=24$

Minimum Length of $\mathrm{Hub}(\mathrm{L})$ :

$\mathrm{L}=\frac{8 T}{6.5 * 248\left(\left(27^{2}\right)-\left(23^{2}\right)\right)}$

$\mathrm{L}=24.63 \mathrm{~mm}$ 


\subsection{Selection of Bearings for Bevel Drive Shafts}

Due to positioning of all the Miter gears, radial forces cancel out, but axial forces double,

Total axial Force $(\mathrm{P})=2 * \mathrm{~F}_{\mathrm{a}}$

$\mathrm{P}=2 * 742.649$

$\mathrm{P}=1485.3 \mathrm{~N}$

Let us select Ball Bearings.

Consider $\mathrm{L}_{10}$ as 850 million revolutions and a load factor of 1.4 ,

$\mathrm{C}=\mathrm{P} *\left(\mathrm{~L}_{10}\right)^{1 / 3}\left(\mathrm{~L}_{\mathrm{f}}\right)$

$\mathrm{C}=1485.3 *(850)^{1 / 3}(1.4)$

$\mathrm{C}=19697.66 \mathrm{~N}$

$\mathrm{C}=19.7 \mathrm{kN}$

$\mathrm{d}=35$ (shaft O.D.)

Selecting Double Row Ball bearings from SKF catalogue:

[4]

Table -1: Designation Number 4207 ATN9

\begin{tabular}{|l|l|l|l|}
\hline $\mathrm{d}(\mathrm{mm})$ & $\mathrm{D}(\mathrm{mm})$ & $\mathrm{B}(\mathrm{mm})$ & $\mathrm{C}(\mathrm{kN})$ \\
\hline 35 & 72 & 23 & 35.1 \\
\hline
\end{tabular}

\section{DESIGN OF WORM \& WORM WHEEL [2]}

\subsection{Constraints for Worm Gears}

Centre distance $(\mathrm{X})$ $=105 \mathrm{~mm}$

Velocity ratio (V.R.) $=7(7: 1)$

Number of starts on worm $\left(Z_{\mathrm{w}}\right) \quad=4$

Normal pressure angle $\left(\psi_{\mathrm{r}}\right) \quad=20$

\subsection{Sizing of Worm \& Worm Wheel}

Number of Teeth on Worm Wheel $\left(Z_{g}\right)$ :

$\mathrm{Z}_{\mathrm{g}}=\mathrm{VR} * \mathrm{Z}_{\mathrm{w}}$

$=7 * 4=28$ teeth

\section{Lead Angle of Worm $(\lambda):[5]$}

$\lambda=\cot ^{-1}(\sqrt[3]{V R})$

$\lambda=\cot ^{-1}(\sqrt[3]{7})$

$\lambda=27.61^{\circ}$

Helix Angle of Worm Wheel ( $\varphi)$ :

$\varphi=\lambda$

$\varphi=27.61^{\circ}$

\section{Helix Angle of Worm $(\gamma)$}

$\varphi+\gamma=90^{\circ}$

$\gamma=90-27.61$

$\gamma=62.39^{\circ}$

Preliminary Worm Diameter

$\mathrm{D}_{\mathrm{w}}=\frac{(x)^{0.875}}{1.416}$

$\mathrm{D}_{\mathrm{w}}=\frac{(105)^{0.875}}{1.416}=41.42 \approx 42 \mathrm{~mm}$

\section{Preliminary Worm Wheel Diameter}

$\mathrm{D}_{\mathrm{G}}=2(\mathrm{x})-\mathrm{D}_{\mathrm{w}}$

$=2(105)-42$

$=168 \mathrm{~mm}$

Circular Pitch $\left(\mathbf{P}_{\mathbf{c}}\right)$ :

$\mathrm{P}_{\mathrm{c}}=\frac{\pi D g}{Z g}=\frac{\pi * 168}{28}=18.9 \mathrm{~mm}$

Axial pitch $=$ Circular Pitch

$\mathrm{P}_{\mathrm{a}}=\mathrm{P}_{\mathrm{c}}=18.9 \mathrm{~mm}$

Module $=\frac{P a}{\pi}=\frac{18.9}{\pi}=6.01$

$\therefore$ Taking modulus as 6

Actual circular pitch $=$ Actual axial pitch

$=\pi * \mathrm{~m}$

$=3.14 * 6$

$=18.84$

Actual wheel diameter $\left(\mathrm{D}_{\text {gactual }}\right)$

$\mathrm{D}_{\text {gactual }}=\mathrm{m} * \mathrm{Z}_{\mathrm{g}}$

$=6 * 28$

$=168 \mathrm{~mm}$

(P.C.D.)

Actual worm diameter $\left(\mathrm{D}_{\text {wactual }}\right)$

$\mathrm{D}_{\text {wactual }}=2(x)-\mathrm{D}_{\mathrm{g} \text { (actual) }}$

$\mathrm{D}_{\mathrm{w}}=2(105)-168$

$\mathrm{D}_{\mathrm{w}}=42 \mathrm{~mm}$ (P.C.D.)

\section{Diametral Quotient (q):}

$\mathrm{q}=\frac{Z w}{\tan \lambda}=\frac{4}{\tan (27.61)}=7.65$

Face Width (b) (of Worm Gear):

$\left.\begin{array}{l}\mathrm{b}=2 \mathrm{~m} \sqrt{q+1} \\ \text { or } \\ \mathrm{b}=0.73 \mathrm{~d}_{\mathrm{w}}\end{array}\right\}$ whichever is greater

$\mathrm{b}=2(6) \sqrt{7.65+1}$ orb $=0.73 * 42$

$\mathrm{b}=35 \mathrm{~mm} \quad$ or $\mathrm{b}=30.66 \mathrm{~mm}$

$\therefore \mathrm{b}=35 \mathrm{~mm}$ 


\section{Lead of Worm (L):}

$\mathrm{L}=\mathrm{Z}_{\mathrm{w}} * \mathrm{P}_{\mathrm{a}(\text { actual })}$

$\mathrm{L}=4 * 18.9$

$\mathrm{L}=75.36 \mathrm{~mm}$

\section{Normal Module $\left(M_{n}\right)$ :}

$\mathrm{M}_{\mathrm{n}}=\mathrm{M} * \cos \lambda$

$=6 * \cos (27.61)$

$=5.3 \mathrm{~mm}$

$=6 \mathrm{~mm}$

Height of the addendum $\left(\mathrm{h}_{\mathrm{a}}\right)=1 * \mathrm{M}_{\mathrm{n}}=6 \mathrm{~mm}$

Height of the dedendum $\left(\mathrm{h}_{\mathrm{f}}\right)=1.25 * \mathrm{M}_{\mathrm{n}}=7.5 \mathrm{~mm}$

Clearance $(\mathrm{CL})=\mathrm{h}_{\mathrm{f}} * \mathrm{~h}_{\mathrm{a}}=1.5 \mathrm{~mm}$

Length of worm $\left(\mathrm{L}_{\mathrm{w}}\right)$

$\mathrm{L}_{\mathrm{w}}=\pi * \mathrm{~m}\left[4.5+\frac{Z g}{50}\right]$

$=96 \mathrm{~mm}$

\subsection{Material Selection \& Force Analysis of Worm \&}

\section{Worm Wheel}

Speed of worm $\left(\mathrm{N}_{\mathrm{w}}\right)=4100 \mathrm{rpm}$

Speed of worm wheel $\left(\mathrm{N}_{\mathrm{g}}\right)=585.71 \mathrm{rpm}$

\section{Pitch Line Velocity of Worm Wheel (V):}

$\mathrm{V}=\frac{\pi * D a * N a}{60000}=\frac{\pi * 162 * 585.71}{60000}=5.15 \mathrm{~m} / \mathrm{s}$

Velocity Factor $\left(\mathbf{C}_{\mathrm{V}}\right)$ :

$\mathrm{C}_{\mathrm{V}}=\frac{6}{6+V}=\frac{6}{6+5.15}=0.538$

We know that for 20 involute teeth from Lewis factor $\left(\mathrm{y}^{\prime}\right)$ :

$\mathrm{y}^{\prime}=0.154-\frac{0.912}{\mathrm{Zep}}$

$\mathrm{y}^{\prime}=0.154-\frac{0.912}{28}=0.121$

\section{Material Selection}

Worm threads are subjected to fluctuating stresses and a large number of stress cycles. Therefore surface endurance strength is an important criterion in the selection of worm material.

The core of the worm should be kept ductile and tough to ensure maximum energy absorption. The worms are therefore made of case hardened steel with a surface hardness of $60 \mathrm{HRC}$ and a case depth of 0.75 to $4.5 \mathrm{~mm}$.

We have chosen a Nickel-Chromium alloy steel: $15 \mathrm{Ni} 4 \mathrm{Cr} 1[1]$

The magnitude of contact stresses on the worm wheel teeth is the same as that on the worm threads.

However the number of stress cycles is reduced by a factor equal to the speed reduction. The worm wheel cannot be accurately generated byhobbing process. The final profile and finish of the worm wheel teeth is the result of plastic deformation during initial stages of service. Therefore the worm wheel material should be soft and conformable.

Phosphor Bronze with a surface hardness of 90 to $120 \mathrm{BHN}$, is widely used for the worm gear. Phosphor Bronze worm wheel are sand cast, sand cast and chilled or centrifugally cast. Phosphor Bronze is costly and in case of worm wheel with large dimensions, only the outer rim is made of Phosphor Bronze. It is then bolted into the cast iron wheel. There are two reasons for using dissimilar or heterogeneous materials for worms and worm wheel:

(i) The coefficient of friction is reduced.

(ii) The conformability of worm wheel with respect to the worm is improved.

\section{Worm Material}

15Ni4Cr1 (Case Hardened)

$\mathrm{S}_{\mathrm{ut}}=1500 \mathrm{~N} / \mathrm{mm}^{2}$

$\mathrm{BHN}=650$

Allowable Bending stress ( $\left.\sigma_{\text {allowable }}\right)$ :

\section{Worm Wheel Material}

$$
\sigma_{b \text { allowable }}=\frac{\text { Sut }}{3}=\frac{1500}{3}=500 \mathrm{~N} / \mathrm{mm}^{2}
$$

Phosphor Bronze

$\mathrm{S}_{\mathrm{ut}}=240 \mathrm{~N} / \mathrm{mm}^{2}$

$\mathrm{BHN}=70$

Load stress factor $(\mathrm{k})=0.55 \mathrm{~N} / \mathrm{mm}^{2}$

$$
\sigma_{b \text { allowable }}=\frac{\text { Sut }}{3}=\frac{240}{3}=80 \mathrm{~N} / \mathrm{mm}^{2}
$$

\section{Check for Tangential Load Transmitted (FT):}

$F_{T}=\sigma b * C v * b * \pi * m * y^{\prime}$

$\mathrm{F}_{\mathrm{T}}=80 * 0.538 * 35 * \pi * 6 * 0.121$

$\mathrm{F}_{\mathrm{T}}=3447.08 \mathrm{~N}$

Power transmitted due to tangential load $\left(\mathrm{P}_{\mathrm{T}}\right)$

$\mathrm{P}_{\mathrm{T}}=\frac{F * V}{1000}=\frac{3447.08 * 5.15}{1000}=17.75 \mathrm{~kW}$

Since this is more than the power to be transmitted, DESIGN IS SAFE

\section{Check for Dynamic Load (FD):}

$$
\mathrm{F}_{\mathrm{D}}=\frac{F t}{C . V .}=\frac{3447.08}{0.538}=6405.6 \mathrm{~N}
$$

Power transmitted due to dynamic load $\left(\mathrm{P}_{\mathrm{D}}\right)$

$$
\mathrm{P}_{\mathrm{D}}=\frac{F d * V}{1000}=\frac{6405.6 * 5.15}{1000}=32.98 \mathrm{~kW}
$$

Since this is more than the power to be transmitted, DESIGN IS SAFE 


\section{Check for Static Load}

Flexural Endurance limit $\left(\mathrm{F}_{\mathrm{c}}\right)$

$\mathrm{F}_{\mathrm{c}}=1.75(\mathrm{BHN})$

$\mathrm{F}_{\mathrm{c}}=1.75(70)$

$\mathrm{F}_{\mathrm{c}}=122.5 \mathrm{~N} / \mathrm{mm}^{2}$

Static load $\left(\mathrm{F}_{\mathrm{s}}\right)$

$\mathrm{F}_{\mathrm{s}}=\mathrm{F}_{\mathrm{c}} * \mathrm{~b} * \pi * \mathrm{~m} * \mathrm{y}^{\prime}$

$\mathrm{F}_{\mathrm{s}}=122.5 * 35 * \pi * 6 * 0.121$

$\mathrm{F}_{\mathrm{s}}=9808.575 \mathrm{~N}$

Power transmitted due to static load $\left(\mathrm{P}_{\mathrm{S}}\right)$

$$
\mathrm{P}_{\mathrm{S}}=\frac{F s * V}{1000}=\frac{9808.575 * 5.15}{1000}=50.51 \mathrm{~kW}
$$

Since this is more than the power to be transmitted, DESIGN IS SAFE.

\section{Check for Wear Load}

Wear load $\max _{\text {max }}=\mathrm{D}_{\mathrm{G}} * \mathrm{~b} * \mathrm{~K}$

$\mathrm{F}_{\mathrm{w}}=168 * 35 * 0.55$

$\mathrm{F}_{\mathrm{w}}=3234 \mathrm{~N}$

Power transmitted due to wear load $\left(\mathrm{P}_{\mathrm{w}}\right)$

$$
\mathrm{P}_{\mathrm{w}}=\frac{F w * V}{1000}=\frac{3234 * 5.15}{1000}=16.65 \mathrm{~kW}
$$

Since this is more than the power to be transmitted, DESIGN IS SAFE

\section{Rubbing Velocity $\left(\mathbf{V}_{s}\right)$ :}

Rubbing Velocity $\left(\mathrm{V}_{\mathrm{s}}\right)=\frac{\text { Vworm }}{\cos \lambda}$

$$
\begin{gathered}
\frac{\text { Vworm }}{\cos \lambda}=\frac{\pi * D w * N w}{60000} \\
\mathrm{~V}_{\mathrm{S}}=\frac{\pi * D w * N w}{60000 * \cos \left(\mathrm{Q}_{\mathrm{a}}\right)} \\
\mathrm{V}_{\mathrm{S}}=\frac{\pi * 42 * 4100}{60000 * \cos (27.61)} \\
\mathrm{V}_{\mathrm{S}}=10.17 \mathrm{~m} / \mathrm{s}
\end{gathered}
$$

From graph of coefficient of friction v/s rubbing speed, we find that the coefficient of friction corresponding to rubbing velocity of $10.17 \mathrm{~m} / \mathrm{s}=0.02(\mu)$

Friction Angle $\left(\emptyset_{\mathrm{F}}\right)$ :

$$
\emptyset_{\mathrm{F}}=\tan ^{-1}(\mu)
$$

$\emptyset_{\mathrm{F}}=\tan ^{-1}(0.02)$

$\emptyset_{\mathrm{F}}=1.146^{\circ}$

\section{Overall Efficiency of Worm and Worm Wheel ( $\eta)$ :}

$$
\begin{aligned}
& \eta=\frac{\tan (\lambda)}{\tan (\lambda+\varnothing \mathrm{F})} \\
& =\frac{\tan (27.61)}{\tan (27.61+1.145)} \\
& =0.95=95 \%
\end{aligned}
$$

\subsection{Self-Locking or Over-Running?}

In general, the worm is the driver and the worm wheel is the driven member and the reverse motion is not possible. This is called "self-locking" drive, because the worm wheel cannot drive the worm. As for screw threads, the criterion for self-locking is a relationship between the coefficient of friction and lead angle. A worm gear drive is said to be selflocking if the coefficient of friction is greater than the tangent of lead angle, i.e. the friction angle is more than the lead angle. This can be written as

$$
\mu>\tan \lambda
$$

There is another term, reversible or over running or 'back driving' worm gear drive. In this type of drive, the worm and the worm wheel can drive each other. In general the worm is the driver and the worm wheel is the driven member. If the driven machinery has large inertia and if the driving power supply is cut off suddenly, the worm is freely driven by the worm wheel. This prevents damage to the drive and source of power. A worm gear drive is said to be reversible if the coefficient of friction is less than tangent of the lead angle i.e. the friction angle is less than the lead angle. This can be written as

$$
\mu<\tan \lambda
$$

$\mu=0.02$

$\lambda=27.61^{\circ}$

$\tan (27.61)=0.523$

$\mu<0.523$

Thus the system is "OVER RUNNING"

\subsection{Strength Rating of Worm \& Worm Wheel}

Table -2: Strength Rating Factors

\begin{tabular}{|l|l|l|}
\hline & WORM & WHEEL \\
\hline Speed Factor $\left(\mathrm{X}_{\mathrm{b}}\right)$ & 0.18 & 0.32 \\
Bending Stress $\left(\mathrm{S}_{\mathrm{b}}\right)$ & 35.32 & 5 \\
\hline
\end{tabular}

$\mathrm{T}=17.65 * \mathrm{X}_{\mathrm{b}} * \mathrm{~S}_{\mathrm{b}} * \mathrm{~m} * \mathrm{~b} * \mathrm{D}_{\mathrm{G}} * \cos \lambda$

Maximum torque on worm $\left(\mathrm{T}_{\mathrm{wmax}}\right)$

$\mathrm{T}_{\mathrm{w} \max }=17.65 * 0.18 * 35.32 * 6 * 35 * 168 * \cos (27.61)$

$=3508368.71 \mathrm{Nmm}$

Maximum torque on worm wheel $\left(\mathrm{T}_{\mathrm{gmax}}\right)$

$\mathrm{T}_{\mathrm{gmax}}=17.65 * 0.32 * 5 * 6 * 35 * 168 * \cos (27.61)$

$=882941.67 \mathrm{Nmm}$ 
Considering lesser of the two;

Power transmitting capacity based on beam strength,

$\mathrm{P}=\frac{2 \pi N T}{60 *\left(10^{6}\right)}=\frac{2 \pi * 455.55 * 882941.67}{60 *\left(10^{6}\right)}$

$\mathrm{P}=54.13 \mathrm{~kW}$

Since this is greater than the power to be transmitted, design is safe.

\subsection{Wear Rating of Worm \& Worm Wheel}

Table -3: Wear Rating Factors

\begin{tabular}{|l|l|l|}
\hline & WORM & $\begin{array}{l}\text { WORM } \\
\text { WHEEL }\end{array}$ \\
\hline SPEED FACTOR $\left(\mathrm{X}_{\mathrm{C}}\right)$ & 0.065 & 0.13 \\
SURFACE STRESS FACTOR $\left(\mathrm{S}_{\mathrm{C}}\right)$ & 6.19 & 1.06 \\
ZONE FACTOR $\left(\mathrm{Y}_{\mathrm{Z}}\right)$ & 1.05 & 1.05 \\
\hline
\end{tabular}

$\mathrm{T}=18.64 * \mathrm{X}_{\mathrm{C}} * \mathrm{~S}_{\mathrm{C}} * \mathrm{Y}_{\mathrm{Z}} *\left(\mathrm{~d}_{\mathrm{g}}\right)^{1.8} * \mathrm{~m}$

Permissible Torque on worm $\left(\mathrm{T}_{\mathrm{wmax}}\right)$

$\mathrm{T}_{\mathrm{wmax}}=18.64 * 0.065 * 6.19 * 1.05 *(168)^{1.8} * 6$

$=478571.87 \mathrm{Nmm}$

Permissible Torque on worm wheel $\left(\mathrm{T}_{\text {gmax }}\right)$

$\mathrm{T}_{\mathrm{gmax}}=18.64 * 0.13 * 1.06 * 1.05 *(168)^{1.8} * 6$

$$
=163905.07 \mathrm{Nmm}
$$

Considering lesser of the two, power transmitting capacity

$\mathrm{P}=\frac{2 \pi N T}{60 *\left(10^{\wedge} 6\right)}=\frac{2 \pi * 585.7143 * 163905.07}{60 *\left(10^{\wedge} 6\right)}$

$\mathrm{P}=10.05 \mathrm{~kW}$

Since this is greater than the power to be transmitted, design is safe.

\subsection{Temperature Rise \& Design Considering Max.}

\section{Permissible Overload}

Heat Generated due to Power Losses $\left(Q_{\mathrm{g}}\right)$ :

$\mathrm{Q}_{\mathrm{g}}=(1-\eta) *$ power input

$\mathrm{Q}_{\mathrm{g}}=(1-0.95) * 5891.3$

$\mathrm{Q}_{\mathrm{g}}=276.412 \mathrm{~W}$

\section{Projected Area of Worm (Aw):}

$\mathrm{A}_{\mathrm{w}}=\frac{\pi(d w)^{2}}{4}=\frac{\pi(42)^{2}}{4}=1384.74 \mathrm{~mm}^{2}$

\section{Projected Area of Worm Wheel (AG):}

$\mathrm{A}_{\mathrm{G}}=\frac{\pi(d g)^{2}}{4}=\frac{\pi(168)^{2}}{4}=22155.84 \mathrm{~mm}^{2}$

Total Projected Area (ATOTAL):

$\mathrm{A}_{\text {TOTAL }}=\mathrm{A}_{\mathrm{w}}+\mathrm{A}_{\mathrm{G}}$

$$
=1384.74+22155.84
$$

$$
\begin{aligned}
& =23540.58 \mathrm{~mm}^{2} \\
& =0.02354058 \mathrm{~m}^{2}
\end{aligned}
$$

Thermal conductivity (K): $378 \mathrm{~W} / \mathrm{m}^{20} \mathrm{C}$

\section{Temperature $\operatorname{Rise}(\delta \mathrm{T})$ :}

$\delta T=\frac{Q g}{\text { Atotal } * K}=\frac{276.412}{0.02354058 * 378}=31.06^{\circ} \mathrm{C}$

The temperature must not show a rise greater than $38^{\circ} \mathrm{C}$ $(\delta T)$, and temperature of lubrication oil should be maintained at less than or around $60^{\circ} \mathrm{C}$, so that the viscosity index is maintained, (considering a mineral oil).

Also if the oil gets too hot, viscosity will drop, but also due to higher temperature seals may get damaged.

Since the system normally only produces a temperature rise of up to $34.19^{\circ} \mathrm{C}$ and max. permissible rise is normally to be kept under $38^{\circ} \mathrm{C}$ we can allow overloading conditions, so long as temperature rise is below $38^{\circ} \mathrm{C}$

Max overload permissible $=\frac{38}{34.19} * 100 \% \approx 111 \%$

In other words the system can tolerate an overload of $11 \%$

\section{Design of Worm Shaft Considering Overload:}

Percentage Overload $=11 \%$

Torque acting on worm gear $\left(\mathrm{T}_{\mathrm{g}}\right)$

$\mathrm{T}_{\mathrm{g}}=\frac{\left(1+\frac{11}{100}\right) * \operatorname{Pin} * 60000}{2 \pi N w}$

$\mathrm{T}_{\mathrm{g}}=\frac{\left(1+\frac{11}{100}\right) * 5.891 * 60000}{2 \pi * 585.7143}$

$\mathrm{T}_{\mathrm{g}}=106.66 \mathrm{Nm}$

Torque Acting on Worm Shaft (Ts):

$\mathrm{T}_{\mathrm{s}}=\frac{T g}{\eta * V \cdot R}$

$\mathrm{T}_{\mathrm{s}}=\frac{106.66}{0.95 * 7}$

$\mathrm{T}_{\mathrm{s}}=15.988655 \mathrm{Nm}$ or $15988.655 \mathrm{Nmm}$

Tangential Force on Worm (FTWORM):

$\mathrm{F}_{\text {TWORM }}=\frac{T s * 1000}{(D w / 2)}=\frac{15988.655}{(42 / 2)}=761.364 \mathrm{~N}$

\section{Axial Force on Worm (FAWORM):}

$\mathrm{F}_{\text {Aworm }}=\frac{T g * 1000}{(D w / 2)}=\frac{106.66 * 1000}{(42 / 2)}=1269.87 \mathrm{~N}$

\section{Radial Force on Worm (FRWORM):}

$\mathrm{F}_{\text {Rworm }}=\frac{\text { Faworm }}{\tan (\emptyset n)}=\frac{1269.87}{\tan (20)}=461.94 \mathrm{~N}$ 


\section{Bending Moment:}

Bending moment due to Radial Force in vertical Plane: (considering distance between bearings equal to $\mathrm{D}_{\mathrm{g}}$ )

$=\frac{\text { Frworm } * D g}{4}$

$=\frac{461.94 * 168}{4}=19401.5579 \mathrm{Nmm}$

Bending moment due to Axial Force in vertical Plane $=\frac{\text { Faworm } * D g}{4}$

$=\frac{1269.87 * 42}{4}=13333.6767 \mathrm{Nmm}$

Total bending moment in vertical plane $=19401.5579+$ 13333.6767

$=32735.2346 \mathrm{Nmm}$

Bending moment due to Tangential Force in Horizontal direction:

$=\frac{\text { Ftworm } * D g}{4}$

$=\frac{761.364 * 168}{4}=31977.3103 \mathrm{Nmm}$

\section{Resultant Bending Moment On Shaft:}

$\mathbf{M}_{\mathrm{worm}}=\sqrt{(B M v)^{2}+(B M h)^{2}}$

$\mathrm{M}_{\mathrm{worm}}=\sqrt{(32735.2346)^{2}+(31977.3103)^{2}}$

$\mathrm{M}_{\mathrm{worm}}=45761.8177 \mathrm{Nmm}$

\section{Equivalent Torsional Moment (Teqv):}

$\mathrm{T}_{\mathrm{eqv}}=\sqrt{(T s)^{2}+(\text { Mworm })^{2}}$

$\mathrm{T}_{\mathrm{eqv}}=\sqrt{(15988.655)^{2}+(45761.8177)^{2}}$

$\mathrm{T}_{\mathrm{eqv}}=48474.5402 \mathrm{Nmm}$

Inner Diameter $\left(\mathrm{d}_{\mathrm{i}}\right)=21.85 \mathrm{~mm}$

Outer Diameter $\left(\mathrm{d}_{\mathrm{o}}\right)=30 \mathrm{~mm}$

$\tau_{\text {actual }}=\frac{16 T}{\pi(D o)^{3}\left(1-\left(C^{4}\right)\right)} \sqrt{(M b)^{2}+(M t)^{2}}$

where, $\mathrm{C}=\frac{\mathrm{di}}{d o}$

$\tau_{\text {actual }}=$

$\frac{\tau_{\text {actual }}=}{\pi(30)^{3}\left(1-\left(\left(\frac{21.85}{30}\right) C^{4}\right)\right)} \sqrt{(45761.8177)^{2}+(48474.5402)^{2}}$

$\tau_{\text {actual }}=17.507 \mathrm{~N} / \mathrm{mm}^{2}$

Permissible Shear Stress (тper)

$\tau_{\text {per }}=\frac{0.5 \text { Sut }}{\text { FOS }}$

Consider a factor of safety of 3 , $\tau_{\text {per }}=\frac{0.5 * 1500}{3}=250 \mathrm{~N} / \mathrm{mm}^{2}$

Since $\tau_{\text {per }>} \tau_{\text {actual, }}$

DESIGN IS SAFE

\subsection{Worm Drive Shaft Spline Calculations}

Permissible pressure on splines $=6.5 \mathrm{~N} / \mathrm{mm}^{2}$ Major Diameter of Splines $\left(D_{\mathrm{s}}\right)=21.81 \mathrm{~mm}$ Minor Diameter of Splines $\left(d_{s}\right)=19.35 \mathrm{~mm}$ Number of Splines $=13$

Minimum Length Of Hub (L):

$\mathrm{L}=\frac{8 T}{6.5 * n *\left(\left(D s^{2}\right)-\left(d s^{2}\right)\right)}$

$\mathrm{L}=\frac{8 T}{6.5 * 13 *\left(\left(21.81^{2}\right)-\left(19.35^{2}\right)\right)}$

$\mathrm{L}=14.9 \mathrm{~mm}$

\subsection{Selection of Bearings for Worm Drive Shafts[2]}

$\mathrm{F}_{\mathrm{R}}=461.94 \mathrm{~N}$

$\mathrm{F}_{\mathrm{A}}=1269.87 \mathrm{~N}$

Shaft OD $=30 \mathrm{~mm}$

$\mathrm{P}=\mathrm{XVF} \mathrm{F}_{\mathrm{R}}+\mathrm{YF}_{\mathrm{A}}$

$\mathrm{V}=1$ (where $\mathrm{V}=$ race rotation factor)

$\frac{F a}{C o}=\frac{1269.87}{20800}=0.061$

$\frac{F a}{F r}=\frac{1269.87}{461.94}=2.75$

$\therefore \frac{F a}{F r}>\mathrm{e}$

$\mathrm{Y}=1.6-\left(\frac{1.8-1.6}{0.07-0.04}\right) *(0.061-0.04)$

$\mathrm{Y}=1.46$

$\mathrm{X}=0.56$

$\mathrm{P}=(0.56 * 1 * 461.94)+(1.46 * 1269.87)$

$\mathrm{P}=2112.7 \mathrm{~N}$

Consider $\mathrm{L}_{10}$ as life of 300 million revolutions

$\mathrm{C}=\mathrm{P} *\left(\mathrm{~L}_{10}\right)^{1 / 3} *\left(\mathrm{~L}_{\mathrm{f}}\right)($ Ball Bearings $)$

$\mathrm{C}=2112.7(300)^{1 / 3}(1.2)\left(\mathrm{L}_{\mathrm{f}}=\right.$ Load Factor $\left.=1.2\right)$

$\mathrm{C}=16971.7 \mathrm{~N}$

$\mathrm{C}=16.97 \mathrm{kN}$

$\therefore$ Bearing selected is from SKF Catalogue: [4]

Table -4: Designation Number 4206 ATN9

\begin{tabular}{|l|l|l|l|}
\hline $\mathrm{d}(\mathrm{mm})$ & $\mathrm{D}(\mathrm{mm})$ & $\mathrm{B}(\mathrm{mm})$ & $\mathrm{C}(\mathrm{kN})$ \\
\hline 30 & 62 & 20 & 26 \\
\hline
\end{tabular}




\section{IMAGES OF THE WORM DIFFERENTIAL}

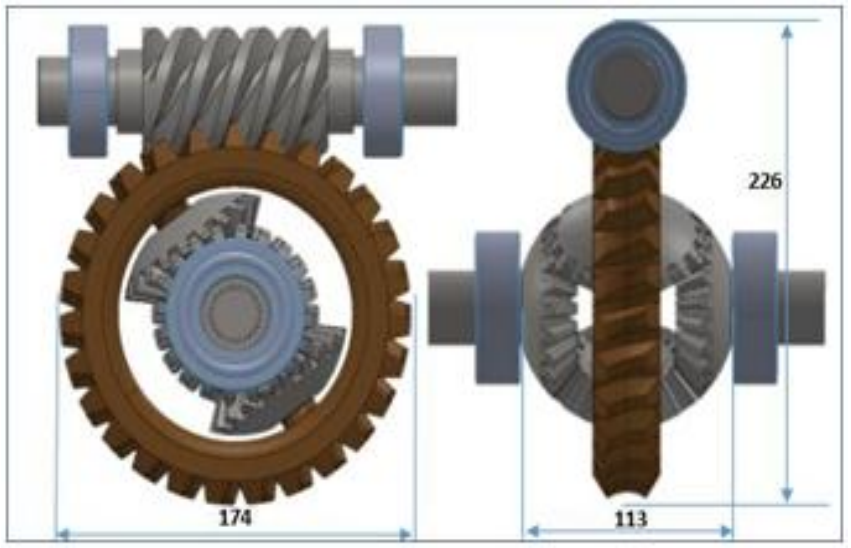

Fig -1: Square Dimensions (mm)

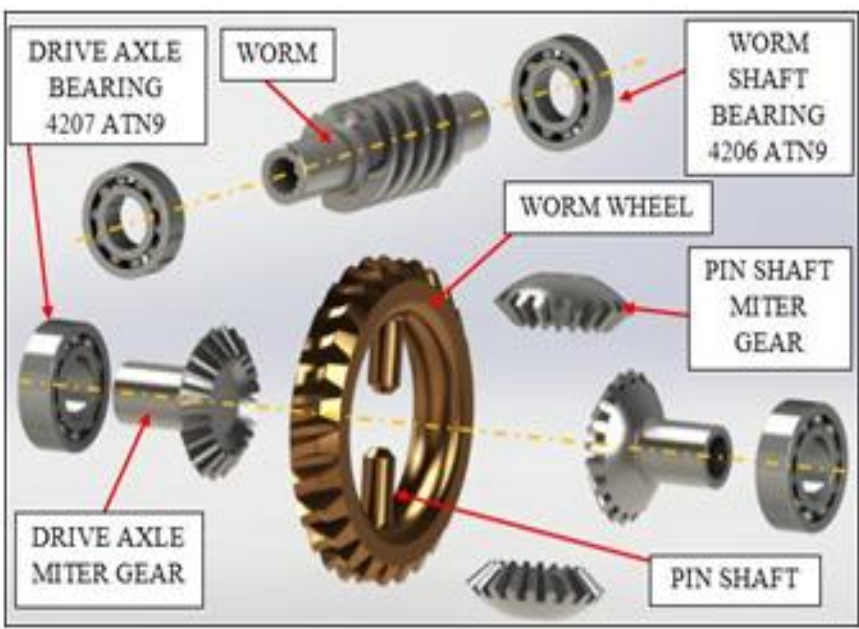

Fig -2: Exploded view of Worm Differential

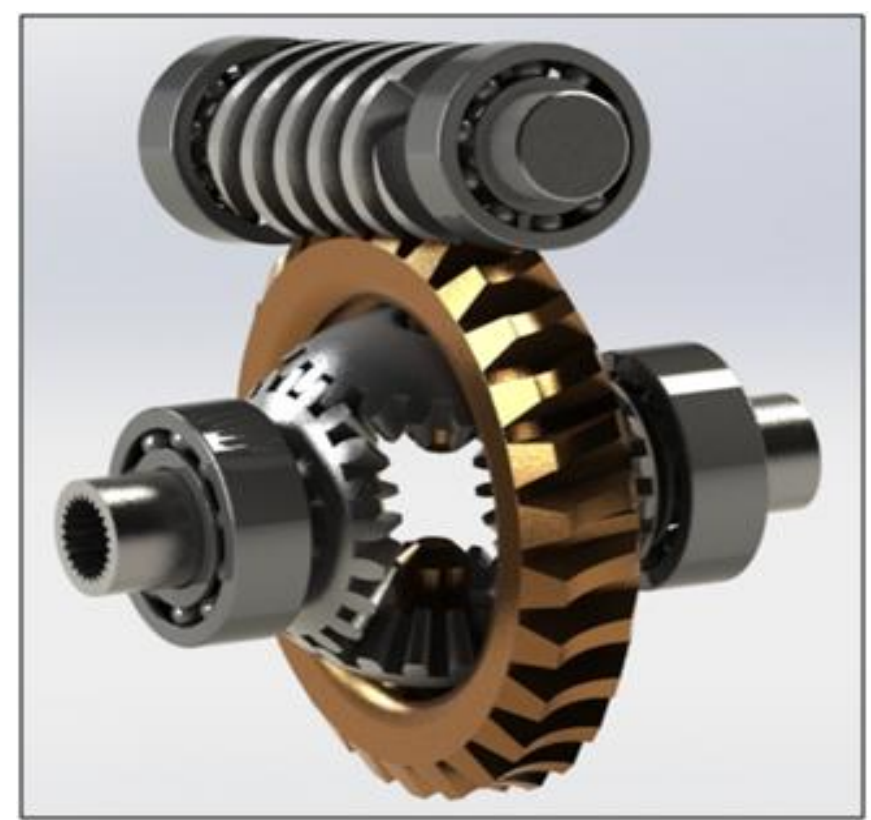

Fig -3: Worm Differential Assembly

\section{STRENGTH BASED ANALYSIS}

Given the complicated geometry of the teeth on worm wheel $\&$ threads on worm, it is difficult to calculate the actual deflection on their surfaces upon maximum load condition. [3]To simplify our task and save us from performing huge matrix calculations, we can use Altair Hypermeshto mesh and analyze the stresses \& deflections of individual parts.

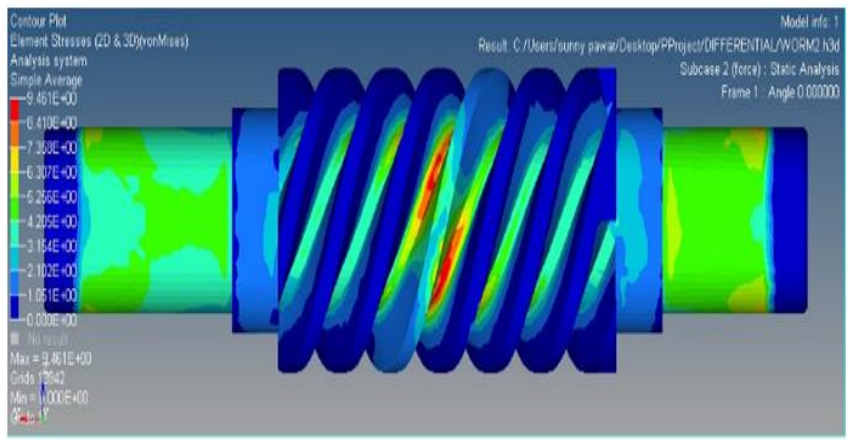

Fig -4: Maximum Von Mises Stress on Worm: 9.46 N/mm²

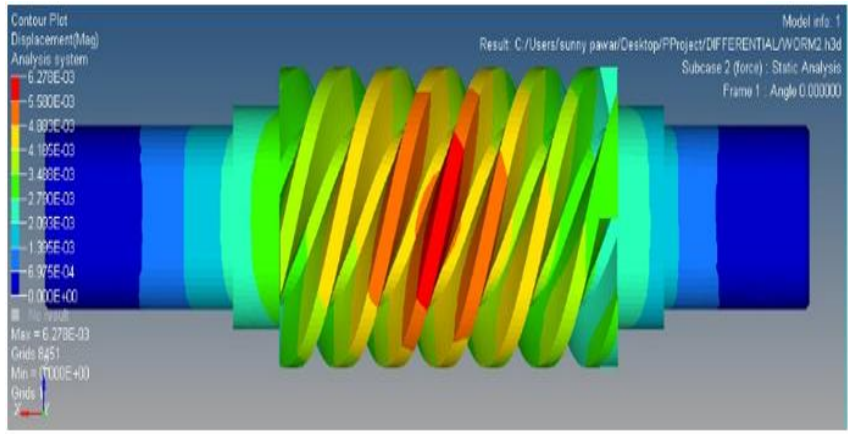

Fig -5: Maximum Deflection of Worm: $6.278 * 10^{-3} \mathrm{~mm}$

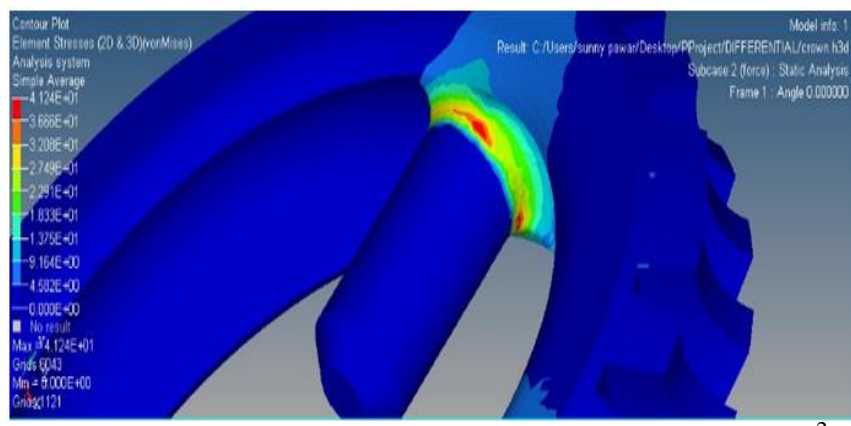

Fig -6: Max. V. M. Stress on Worm Wheel: $41.24 \mathrm{~N} / \mathrm{mm}^{2}$

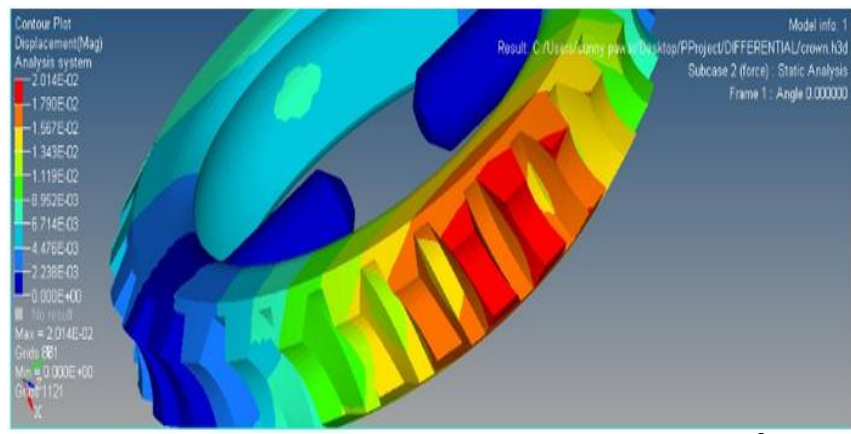

Fig -7: Max. Deflection of Worm Wheel: $2.014 * 10^{-2} \mathrm{~mm}$ 


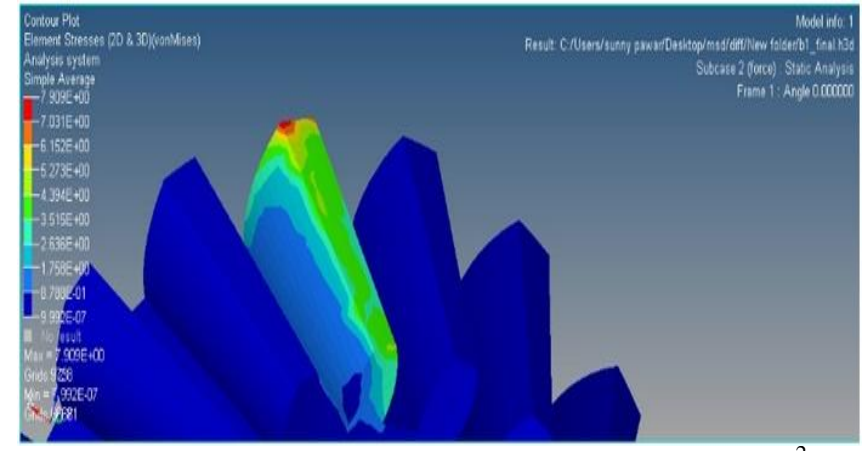

Fig -8: Max. . M. Stress on Miter Gear: 7.909 N/mm²

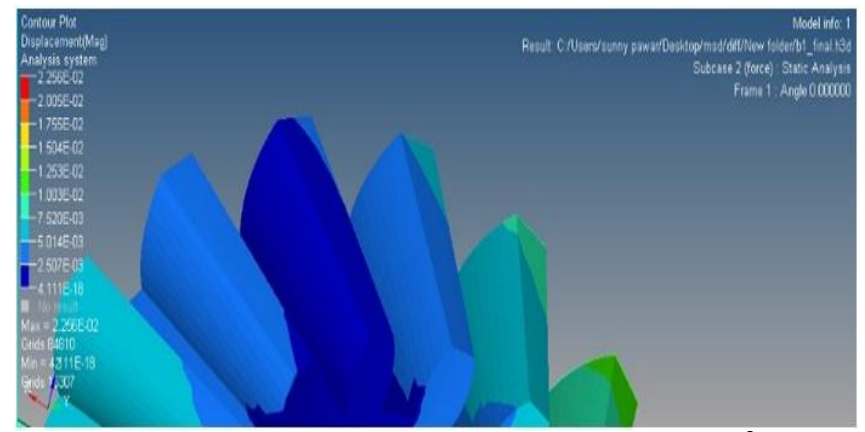

Fig -9: Max. Deflection of Miter Gear: $2.256 * 10^{-2} \mathrm{~mm}$

Table -5: Summary of Stresses \& Deflection

\begin{tabular}{|l|l|l|l|}
\hline $\begin{array}{l}\text { ANALYSIS } \\
\text { OF: }\end{array}$ & $\begin{array}{l}\text { FORCE } \\
(\mathrm{N})\end{array}$ & $\begin{array}{l}\text { STRESS } \\
\left(\mathrm{N} / \mathrm{mm}^{2}\right)\end{array}$ & $\begin{array}{l}\text { DEFLECTION } \\
(\mathrm{mm})\end{array}$ \\
\hline Worm & $\left(\mathrm{F}_{\mathrm{T}}\right) 3447.08$ & 9.46 & $6.278 * 10^{-3}$ \\
$\begin{array}{l}\text { Worm Wheel } \\
\text { Miter Gears }\end{array}$ & $\left(\mathrm{F}_{\mathrm{A}}\right) 3447.08$ & 41.24 & $2.014 * 10^{-2}$ \\
$\left(\mathrm{~F}_{\mathrm{T}}\right) 2886.02$ & 7.909 & $2.256 * 10^{-2}$ \\
\hline
\end{tabular}

From the table above it can be seen that the stresses incurred by the parts are less than the permissible limit. The deflections are of the order of $10^{-2} \& 10^{-3} \mathrm{~mm}$ and hence can be considered negligible. Thus the DESIGN IS SAFE.

\section{ADVANTAGES \& DISADVANTAGES}

\subsection{Advantages}

- Compact.

- $\quad$ Light weight.

- Reduction ratio of even 20:1 is possible by this method.

- Worm shaft is placed higher in this arrangement near the underbelly of the chassis thus less prone to damage.

- $\quad$ Entire structure is centralized in terms of mass \& since C.G. is in the center the positioning is easier.

- $\quad$ The entire differential offers rotational flexibility about the drive axle axis thus the worm shaft can be tilted at any angle without any trouble or complications. This will not affect the design calculations nor increase design complexity.
- The entire enclosure floats around the mechanism. Once disconnected from its mounting, both the shells can come apart offering maintenance worker complete access to the mechanism from any angle.

- Design is very simple and has good serviceability.

\subsection{Disadvantages}

- Limited efficiency at best up to $95 \%$.

- Due to poorer efficiency, temperature rise must be within permissible limits or else seals may get damaged. Also excessive temperature could lead to tooth failure due to seizure.

- The entire system is made of two metals. The worm wheel normally has to be made of a more conformable metal (such as Phosphor Bronze). This may increase costs.

- If the gearing size requirement is larger (for increased torque transmitting capacity), height increases.

- Since the worm wheel is made out of phosphor bronze, whose wear strength is not as high as that of alloy steels, the frequency of replacement of worn out parts may be greater.

\section{SCOPE FOR IMPROVEMENT}

The efficiency mainly gets influenced by the velocity ratio as well as the worm Pitch Circle Diameter (P.C.D.). The lower the velocity ratio and greater the size of the worm P.C.D. the more efficient the system becomes. This in turn reduces power lost as heat as well as the overall heat dissipation requirements of the system.

Since phosphor bronze is an expensive alloy and it has a greater tendency to wear, the best way to save money would be to cast only the outer half of the worm wheel from phosphor bronze and then bolt it onto a cheaper cast iron inner wheel. The miter gears will then be pivoted on the pin shaft made of grey cast iron which is much cheaper. This way less phosphor bronze is consumed per unit of production, reducing material cost. But at the same time the mating surface will have to be machined so this increases production time and cost slightly.

The pivoted bevel gears need not be of the same dimensions as those mounted on the drive axles. They can be of smaller size, thus reducing weight even further \&/or making system more compact.

\section{CONCLUSION}

Overall, the worm gear differential seams viable for heavy, load-carrying vehicles used for construction and material transportation as well as public transport such as buses. The worm gear drive with a very high torque transmitting requirement will have a bigger P.C.D. of worm and wheel, and the overall height may become too much for a consumer vehicle. However for small reduction ratios the system can be made even more compact as mentioned above, hence permitting use in consumer vehicles. 


\section{REFERENCES}

[1]. Design Data Hand Book PSG Coimbatore.

[2]. Design of Machine Elements, 3rd Edition, V.B.

Bhandari, McGraw Hill Publications.

[3]. Practical Finite Element Analysis,Nitin S Gokhale, Sanjay S Deshpande,Sanjeev V Bedekar, Anand N Thite, Finite to Infinite Publications.

[4]. www.skf.com

[5]. A Textbook of Machine Design R S Khurmi, J K Gupta

\section{BIOGRAPHIES}

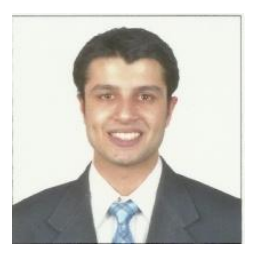

Sumair Sunny, Mechanical Engineering Graduate, M.I.T., Pune

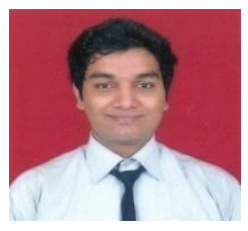

Siddhesh Ozarkar, Mechanical Engineering Graduate, M.I.T., Pune.

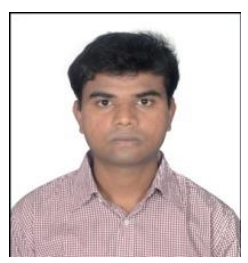

Sunny Pawar, Mechanical Engineering Graduate, M.I.T., Pune 